\title{
Evaluating the Effectiveness of Company Development in Processing Industry
}

\author{
Olga Zinina ${ }^{1, *}$, and Julia Olentsova ${ }^{1}$ \\ ${ }^{1}$ Krasnoyarsk State Agrarian University, Krasnoyarsk, Russia
}

\begin{abstract}
Every company on the market tries to improve its economic stability, which is necessary in order to take a leading competitive position. If a company has been on the market for a long time, has a high financial stability, sales volumes are growing, the financial result of its activities is positive and has a positive dynamic, then we can safely talk about economic stability in the market. This article shows that company development management does not have a universal formula or design, since it reflects the real objective conditions of a specific geographical area or market. At the present stage of market relations development, one of the key problems is to reduce costs in the production of a product and its implementation. Therefore, special attention is paid to the issues of company sustainable development abroad and in Russia.
\end{abstract}

\section{Introduction}

Today, such category as sustainable business development is more and more interesting not only for ordinary entrepreneurs, but also for economists. This directly makes it possible to judge the success of the company in the market. The company's performance can be characterized by a relatively small number of indicators. However, each indicator is affected by a whole system of factors. The system approach provides a comprehensive assessment of various factors impact. Objectively determined factors differ from subjective ways of influencing indicators, so possible organizational and technical measures that can be used to influence the factors that determine this indicator.

The state of the modern market environment is characterized by a significant degree of instability: the state code of laws is changing, the standard of the population living is changing, new players are constantly emerging, the competitive environment is increasing, and every year some other business trends appear and disappear.

The purpose of the work is to develop a mechanism for sustainable development. To achieve this goal, we need to solve the following tasks:

- consider the specific economic environment in which the company operates;

- represent the algorithm for the sustainable development of companies in the meat industry;

- $\quad$ provide evaluating the effectiveness of sustainable company development.

The theoretical and methodological basis of the research is the theoretical and practical positions of local and foreign scientists in the field of industrial production, logistics, and company economics [1,2]. The information base of the study was the primary data and analytical data of a specific company in the Krasnoyarsk region $[3,4]$.

Many Russian and foreign scientists, such as Bowersox D. J., Closs D. J., B. A. Anikin, L. B. Mirotin, Yu. M. Nerush, and others, are devoted to scientific research on the problems of agricultural enterprises functioning.

\section{Materials and methods}

The Krasnoyarsk region occupies $13.7 \%$ of the Russian Federation territory - it is the second largest territory in the Russian Federation and the 13th largest population. The area of agricultural land in the region is 4.9 million hectares, in agricultural organizations - 3.56 million hectares, including 2.4 million hectares of arable land. Despite the fact that the Krasnoyarsk region is located in the zone of risky agriculture, agro-industrial complex is a large and important economic activity and occupies a leading position in the Siberian Federal district [5-7].

The agro-industrial complex of the Krasnoyarsk region is a heterogeneous system that includes agricultural organizations, companies for processing agricultural products, and food production [8-11].

Table 1. Production structure of main crop products by category of farms in the Krasnoyarsk region (as a percentage of total production).

\begin{tabular}{|c|c|c|c|c|}
\hline Indicator & $\mathbf{2 0 1 5}$ & $\mathbf{2 0 1 6}$ & $\mathbf{2 0 1 7}$ & $\mathbf{2 0 1 8}$ \\
\hline $\begin{array}{c}\text { Grains and legumes (in } \\
\text { weight after completion) }\end{array}$ & 86.4 & 84.8 & 83.3 & 81.7 \\
\hline Potato & 7.8 & 9.4 & 8.6 & 8.7 \\
\hline $\begin{array}{c}\text { Open and closed ground } \\
\text { vegetables }\end{array}$ & 11.8 & 12.9 & 10.4 & 9.5 \\
\hline
\end{tabular}

\footnotetext{
* Corresponding author: tutor.eng@yandex.ru
} 
In the structure of crop production, the main share is for cereals and legumes $-81.7 \%$ in 2018 , and the share of cereals is decreasing (in dynamics by 4.7 ), and the share of potatoes is increasing - from $7.8 \%$ in 2015 to $8.7 \%$ in 2018 due to an increase in sown areas. The share of open and closed ground vegetables decreased by $2.3 \%$ to $9.5 \%$ in 2018 .

Argo-industrial holding (AIH) «AgroYarsk» is a company that combines diverse agricultural assets on the basis of a full technological and production cycle, including: production of agricultural products (milk, meat, and grain), its processing (dairy products, meat semi-finished products, flour and bakery products), storage and marketing [12-16]. In table 2, we present the main economic indicators of the organization.

Table 2. Main economic indicators of the AIH «AgroYarsk» for 2016-2018, mln. rub.

\begin{tabular}{|c|c|c|c|c|c|c|c|}
\hline \multirow[t]{2}{*}{$\begin{array}{l}\text { Indicator } \\
S\end{array}$} & \multirow{2}{*}{$\begin{array}{l}2016 \\
\text { year }\end{array}$} & \multirow{2}{*}{$\begin{array}{l}2017 \\
\text { year }\end{array}$} & \multirow{2}{*}{$\begin{array}{l}2018 \\
\text { year }\end{array}$} & \multicolumn{2}{|c|}{\begin{tabular}{|l|l|}
\multicolumn{2}{|l|}{ Deviation } \\
2018 from \\
2016 & \\
\end{tabular}} & \multicolumn{2}{|c|}{$\mid$\begin{tabular}{ll}
\multicolumn{2}{|l}{ Deviation } \\
2018 & from \\
2017 &
\end{tabular}} \\
\hline & & & & $\begin{array}{l}\text { mln. } \\
\text { rub. }\end{array}$ & \begin{tabular}{|l|} 
Rac \\
e, \\
$\%$
\end{tabular} & $\begin{array}{l}\text { mln. } \\
\text { rub. }\end{array}$ & $\begin{array}{l}\text { Race, } \\
\%\end{array}$ \\
\hline $\begin{array}{l}\begin{array}{l}\text { Proceeds } \\
\text { from sales }\end{array} \\
\end{array}$ & $\begin{array}{l}15732 \\
6 \\
\end{array}$ & 45256 & \begin{tabular}{|l|}
17101 \\
3 \\
\end{tabular} & 13687 & \begin{tabular}{|l|}
108 \\
7 \\
\end{tabular} & \begin{tabular}{|l|}
12575 \\
.7 \\
\end{tabular} & 377.9 \\
\hline $\begin{array}{l}\text { Cost of } \\
\text { sales }\end{array}$ & 94299 & 32413 & $\begin{array}{l}10982 \\
6 \\
\end{array}$ & 15527 & $\begin{array}{l}116 \\
5 \\
\end{array}$ & $\begin{array}{l}7741 . \\
3 \\
\end{array}$ & 338.8 \\
\hline \begin{tabular}{|l|} 
Gross \\
profit
\end{tabular} & 63027 & 12843 & 61187 & -1840 & 971 & $\begin{array}{l}4834 . \\
4\end{array}$ & 476.4 \\
\hline $\begin{array}{l}\text { Commerci } \\
\text { al } \\
\text { expenses }\end{array}$ & 7370 & 10226 & 21884 & 14514 & $\begin{array}{l}296 \\
9\end{array}$ & $\begin{array}{l}1165 . \\
8\end{array}$ & 214.0 \\
\hline $\begin{array}{l}\text { Administr } \\
\text { ative } \\
\text { expenses }\end{array}$ & 17729 & 22949 & 25792 & 8063 & $\begin{array}{l}145 \\
5\end{array}$ & 284.3 & 112.4 \\
\hline \begin{tabular}{|l} 
Profit on \\
sales
\end{tabular} & 37927 & 20333 & 13511 & $\begin{array}{l} \\
24416 \\
\end{array}$ & 356 & $-68 ., 2$ & 66.4 \\
\hline $\begin{array}{l}\text { Income } \\
\text { from } \\
\text { participati } \\
\text { on in } \\
\text { other } \\
\text { organizati } \\
\text { ons } \\
\end{array}$ & 666 & - & 12427 & 11761 & $\begin{array}{l}186 \\
59\end{array}$ & $\begin{array}{l}1242 \\
7\end{array}$ & - \\
\hline \begin{tabular}{|l|} 
Interest \\
receiving
\end{tabular} & 948 & 1384 & 514 & -434 & 542 & -87 & 37.1 \\
\hline \begin{tabular}{|l|}
$\begin{array}{l}\text { Interest } \\
\text { payable }\end{array}$ \\
\end{tabular} & 4235 & 12784 & 20940 & 16705 & \begin{tabular}{|l|}
494 \\
5 \\
\end{tabular} & 815.6 & 163.8 \\
\hline $\begin{array}{l}\text { Other } \\
\text { income }\end{array}$ & 54215 & 14947 & 24687 & $\begin{array}{l}- \\
29528 \\
\end{array}$ & 455 & 974 & 165.2 \\
\hline $\begin{array}{l}\text { Other } \\
\text { expenses }\end{array}$ & $\begin{array}{l}10844 \\
5\end{array}$ & 16033 & 29132 & $\begin{array}{l} \\
79313 \\
\end{array}$ & 269 & $\begin{array}{l}1309 . \\
9\end{array}$ & 181.7 \\
\hline $\begin{array}{l}\text { Profit } \\
\text { before tax }\end{array}$ & $\begin{array}{l}- \\
18924\end{array}$ & 32818 & 1066 & 19990 & - & $\begin{array}{l}- \\
3175 . \\
2 \\
\end{array}$ & 3.2 \\
\hline Profit tax & - & - & - & 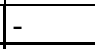 & - & - & - \\
\hline Change & 1632 & -5284 & -1491 & -3123 & - & 379.3 & - \\
\hline Change & 5533 & 11108 & 1383 & -4150 & 250 & -972.5 & 12.5 \\
\hline \begin{tabular}{|l|}
$\begin{array}{l}\text { Other } \\
\text { taxes }\end{array}$ \\
\end{tabular} & -66 & $-0,9$ & 792 & 858 & - & 79.29 & - \\
\hline Net profit & $\begin{array}{l} \\
15089 \\
\end{array}$ & $\begin{array}{l}- \\
26995 \\
\end{array}$ & 1749 & 16838 & - & $\begin{array}{l}2874 . \\
4\end{array}$ & $b^{-}$ \\
\hline
\end{tabular}

Profit from sales decreased both in 2018 compared to 2016 and in 2018 compared to 2017: by $24416 \mathrm{mln}$. rub. and $6822 \mathrm{mln}$. rub., respectively.

We can conclude that the company has strengths that allow it to develop successfully, using opportunities in the global market [17]. At the same time, there are difficulties created by competitors and weaknesses which pose a threat to development, because in the conditions of sanctions, we need to look for new markets for products and investors. In other words, it is necessary to think about a more sustainable development of the company.

\section{Results}

Having carefully analysed the business activity of the company, it should be noted that the AIH «AgroYarsk» does not always consider the correct product adjacency, which must be observed in order to ensure that some types of raw materials do not have a negative impact on others. This often leads to damage to materials, and therefore to unjustified losses, which is a negative point.

Analysis of the storage function showed that there is no standardized information about material flows. There are no basic reference lists of goods and materials that include weight and size parameters, which reduces the ability to manage and plan logistics processes having the nomenclature in tens of thousands of items required for the operation of the company [18-20].

Further we consider the volume of raw materials and supplies in the warehouse of the AIH «AgroYarsk» in table 3.

Table 3. Main economic indicators of the AIH «AgroYarsk» for 2016-2018, mln. rub.

\begin{tabular}{|l|l|l|l|l|}
\hline \multicolumn{1}{|c|}{ Period } & \multicolumn{1}{|c|}{$\begin{array}{c}\mathbf{2 0 1 7} \\
\text { year }\end{array}$} & \multicolumn{1}{|c|}{$\begin{array}{c}\mathbf{2 0 1 8} \\
\text { year }\end{array}$} & $\begin{array}{c}\text { Change, } \\
(\mathbf{\pm})\end{array}$ & $\begin{array}{c}\text { Rate of } \\
\text { change, } \\
\mathbf{\%}\end{array}$ \\
\hline January & 951400 & 955870 & 4470 & 100.5 \\
\hline February & 951400 & 955870 & 4470 & 100.5 \\
\hline March & 833400 & 845570 & 12170 & 101.5 \\
\hline April & 870270 & 882340 & 12070 & 101.4 \\
\hline May & 936650 & 955870 & 19220 & 102.1 \\
\hline June & 958770 & 970570 & 11800 & 101.2 \\
\hline July & 1017770 & 1029390 & 11620 & 101.1 \\
\hline September & 811270 & 823520 & 12250 & 101.5 \\
\hline September & 811270 & 816160 & 4890 & 100.6 \\
\hline October & 767020 & 772050 & 5030 & 100.7 \\
\hline November & 1069400 & 1088220 & 18820 & 101.8 \\
\hline December & 1047280 & 1058810 & 11530 & 101.1 \\
\hline Total & 11025890 & 11154220 & 128330 & 101.2 \\
\hline
\end{tabular}

The issuance level of raw materials to production in 2017 was $95.3 \%$, in 2018 - $95.9 \%$. The dynamics of this indicator is regarded positively. In table 4, we present the calculation of indicators of irregular issuance. 
Table 4. Calculation of irregular coefficients of raw materials and supplies from the warehouse of the AIH «AgroYarsk» in 2018.

\begin{tabular}{|l|c|c|c|c|}
\hline \multicolumn{1}{|c|}{ Indicator } & \multicolumn{1}{|c|}{$\begin{array}{c}\mathbf{2 0 1 7} \\
\text { year }\end{array}$} & $\begin{array}{c}\mathbf{2 0 1 8} \\
\text { year }\end{array}$ & $\begin{array}{c}\text { Change, } \\
( \pm)\end{array}$ & $\begin{array}{c}\text { Rate of } \\
\text { change, } \\
\text { \% }\end{array}$ \\
\hline $\begin{array}{l}\text { Maximum } \\
\text { issuance, } \\
\text { thousand rub. }\end{array}$ & 1069400 & 1088220 & 18820 & 101.8 \\
\hline $\begin{array}{l}\text { Minimum } \\
\text { issuance, } \\
\text { thousand rub. }\end{array}$ & 767020 & 772050 & 5030 & 100.7 \\
\hline $\begin{array}{l}\text { Average } \\
\text { issuance, } \\
\text { thousand rub. }\end{array}$ & 918210 & 930140 & 11930 & 101.3 \\
\hline $\begin{array}{l}\text { Coefficient of } \\
\text { irregular } \\
\text { issuance }\end{array}$ & 1.16 & 1.17 & 0.01 & 100.9 \\
\hline
\end{tabular}

The irregular issuance coefficient of raw materials from the warehouse of the AIH «AgroYarsk» shows that the maximum issuance of raw materials in 2018 is 1.17 times higher than the average. This irregular deliveries and holidays depend on the season. Thus, the largest receipts and issuances are in October and November.

Analysis of the distribution function showed that there is a frequency and multiplicity of received and shipped batches.

Assess the function of transport to the AIH «AgroYarsk».

The company's products are transported in standard containers in boxes or on pallets.

At the same time:

a) if pallets are used, the container can hold 600 items (30 pallets in one container, 12 items on one pallet);

b) if the boxes are used, the container can hold 780 items (45 boxes in one container, 12 items in one box).

Transportation costs per container are: for transportation of $100-249 \mathrm{~km}-600 \mathrm{rub}$; for transportation of $250-499 \mathrm{~km}-900 \mathrm{rub}$; for transportation of $500-999 \mathrm{~km}-1300 \mathrm{rub}$; for transportation of 1000-1999 km - 2100 rub.; for transportation of 2000 and more $\mathrm{km}-3100 \mathrm{rub}$.

In figure 1, we present the dynamics of orders completed in deadline and in disruption of the deadline.

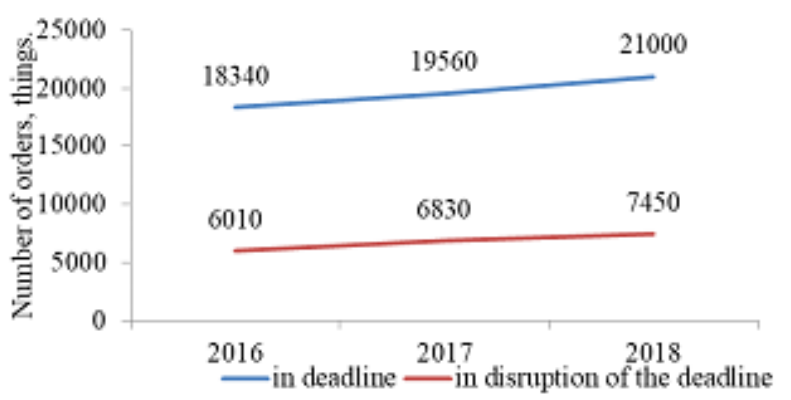

Fig. 1. Dynamics of orders completed in deadline and in disruption of the deadline for 2016-2018.

The number of orders completed in disruption of the deadline increased by 1440 orders. The largest disruption from the deadline was no more than five hours - 5360 orders or $18.8 \%$ (figure 2 ).


Fig. 2. Share of orders with the delivery deadline disruption, $\%$.

The main reason for the delivery deadline disruption can be called: an increase in delivery deadline for transport, an increase in parking deadline on the way; delays on the way for reasons that do not depend on the carrier's company (force majeure).

\section{Discussion}

For diagnosis of efficiency of functioning of the AIH «AgroYarsk» values of indicators are distributed into four zones relative deviation from optimality conditions: - zone of normal functioning of the AIH «AgroYarsk» normalized indicators are within the range of 12 to 15 points; the economic result of economic activity is positive;

- zone of permissible operation of the AIH «AgroYarsk» - normalized values are in the range of 8 to 12 points; zone, within which the amount of potential losses does not exceed the expected profits and, consequently, the functioning of the AIH «AgroYarsk» makes economic sense;

- zone critical for the functioning of the AIH «AgroYarsk» - normalized values are in the range from 4 to 8 points; it is a zone of possible losses exceeds the value of expected profit up to the full value of estimated revenues (costs and profit). In other words, here the company risks not only getting any income, but also may incur direct losses in the amount of all costs incurred;

Look at the overall mechanism for evaluating the efficiency of the AIH «AgroYarsk» in figure 3. 
Calculation of single indicators of the functioning

Translating indicators into relative values (points) based on expert assessments

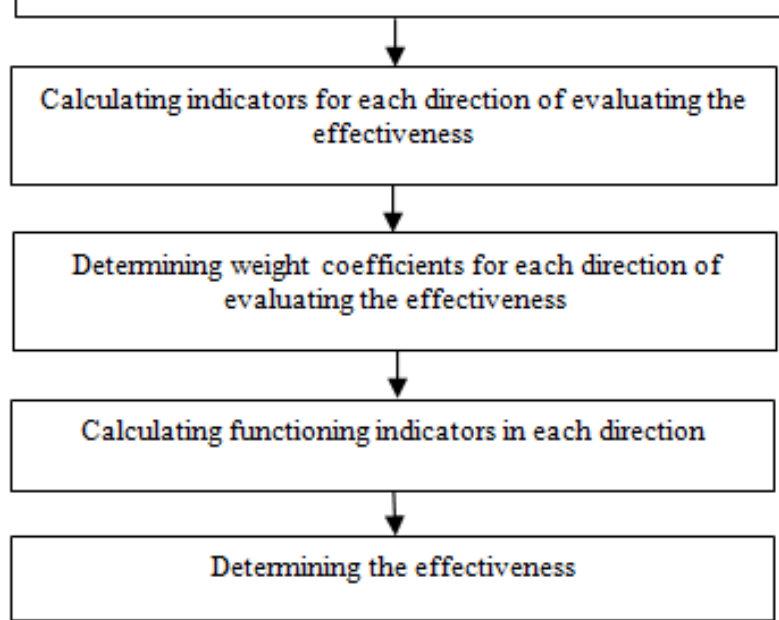

\begin{tabular}{|c|c|c|c|}
\hline $\begin{array}{c}\text { Crisis } \\
\text { function in } \\
\mathrm{g} \text { zone } \\
\text { (0-4 } \\
\text { points) }\end{array}$ & $\begin{array}{l}\text { Critical } \\
\text { functioning } \\
\text { zone (4-8 } \\
\text { points) }\end{array}$ & $\begin{array}{l}\text { Acceptable } \\
\text { function in } \\
\text { g zone (8- } \\
12 \text { points) }\end{array}$ & $\begin{array}{l}\text { Normal } \\
\text { function in } \\
\text { g zone } \\
\text { (12-15 } \\
\text { points) }\end{array}$ \\
\hline \\
\hline \multicolumn{4}{|c|}{ Calculating the integral functioning } \\
\hline
\end{tabular}

Fig. 3. Mechanism for evaluating the functioning of the AIH «AgroYarsk».

The points used are defined expertly, in a way of consistent comparisons based on the work of the author Lukinsky V.V.

First stage. Calculation of individual indicators for evaluating the functioning of the AIH «AgroYarsk» and conversion of indicators to relative values (points).

To translate indicators into relative values, they are compared with the basic indicators. The basic indicators will be the indicators of the estimated company for 2018 . In order to translate indicators into relative values, a 15point scale is used (15 points are the best score). At the same time, an indicator that has a value worse than the basic one is evaluated with 5 points; 10 points - at the level of the basic one; 15 points - better than the basic one.

There are three possible situations: the worst, at the base value level, and the best. Accordingly, the highest score is divided by three $(15 / 3=5)$. The resulting five points are given to the worst-case scenario (5 points), and another five points are added if the value remains at the base value $(5+5=10$ points $)$. And the best value is rated with a maximum score of 15 points.

Second stage. The calculation of the integral indicator for evaluating the functioning of the $\mathrm{AIH}$ «AgroYarsk».

Determination of criteria and efficiency coefficient for evaluating the functioning of the AIH «AgroYarsk» is carried out using the weighted average arithmetic formula:

$$
\begin{aligned}
& \text { Cint }=0,11 E p+0.12 E s+0.15 E d+ \\
& +0.18 E w a r+0.20 E t r+0.24 E i m
\end{aligned}
$$

where Cint is the integral coefficient for the efficiency of the AIH «AgroYarsk»;

$E p$ is the criteria for efficiency of the company's profitability activities

$E s$ is the criterion for the efficiency of the company's supply activities;

$E d$ is the criterion for the efficiency of a company's distribution activities;

Ewar is the criterion for the efficiency of the company's warehouse activities;

Etr is the criterion for the efficiency of the company's transport activities;

Eim is the criterion for the effectiveness of the company's inventory management;

$0.11,0.12,0.15,0.18,0.20,0.24$ are the weight coefficients, determined in an expert survey of the AIH «AgroYarsk» workers.

The value of the company's supply activities criterion is calculated according to the formula:

$$
E s=0.31 V r+0.69 C i(r)
$$

where Es is the criteria for the efficiency of the company's supply activities;

$V r$ is the receipt volumes of raw materials and materials;

$\mathrm{Ci}(r)$ is the coefficient of irregular receipt of raw materials

$0.31,0.69$ are the weight coefficients.

The value of the company's distribution activities criterion is calculated according to the formula:

$$
E d=0.29 V i+0.35 \mathrm{Li}+0.36 \mathrm{Ci}(r)
$$

where $E d$ is the criterion for the efficiency of a company's distribution activities;

$V i$ is the issuance volumes of raw materials and materials;

$\mathrm{Li}$ is the issuance level of raw materials;

$\mathrm{Ci}(r)$ is the coefficient of irregular receipt of raw materials.

$0.29,0.35,0.36$ are the weight coefficients, determined in an expert survey of the AIH «AgroYarsk» workers.

The value of the company's warehouse activities criterion is calculated according to the formula:

$$
\begin{aligned}
& E w a r=0.07 A c+0.09 C_{u s}{ }^{F}+0.10 C_{u s}{ }^{V}+ \\
& +0.11 g+0.12 \mathrm{M}+0.15 \mathrm{Pl}+0.16 F t+0.20 \mathrm{Vt}
\end{aligned}
$$

where Ewar is the criterion for the efficiency of the company's warehouse activities;

$A c$ is the annual cargo turnover, $\mathrm{t}$;

$C_{u s}{ }^{F}$ is the coefficient of company's useful function;

$C_{u s}{ }^{V}$ is the coefficient of company's useful volume; 
$g$ is the specific load per $1 \mathrm{~m} 2$ of usable area, $\mathrm{t} / \mathrm{m}^{2}$; $\mathrm{t} / \mathrm{m}^{2}$;

$M$ is the load capacity of $1 \mathrm{~m} 2$ of the company's area,

$P l$ is the labor productivity of warehouse workers, $\mathrm{t}$;

$F t$ is the total cargo area of the warehouse, $\mathrm{m}^{2}$;

$V t$ is the total cargo volume of the warehouse, $\mathrm{m}^{3}$.

$0.07,0.09,0.10,0.11,0.12,0.15,0.16,0.20$ are the weight coefficients, determined in an expert survey of the AIH «AgroYarsk» workers.

The value of the company's transport activities criterion is calculated according to the formula:

$$
\begin{aligned}
& E t r=0.14 \mathrm{~T}+0.17 \mathrm{Cr}+0.20 \mathrm{Rd}+ \\
& +0.21 Q p a c+0.28 S d
\end{aligned}
$$

where Etr is the criterion for the efficiency of the company's transport activities;

$T$ is the time from receipt of order to delivery;

$\mathrm{Cr}$ is the completeness of order realization;

$R d$ is the delivery reliability;

Qpac is the quality of transport packaging;

$S d$ is the delivery stability.

$0.14,0.17,0.20,0.21,0.28$ are the weight coefficients, determined in an expert survey of the AIH «AgroYarsk» workers.

The value of the company's transport activities criterion is calculated according to the formula:

$$
\text { Eim }=0,25 T i+0,32 \text { Dit }+0,43 P i
$$

where Eim is the criterion for the effectiveness of the company's inventory management;

$T i$ is the inventory turnover;

Dit is the duration of inventory turnover;

$P i$ is the profitability of inventory;

$0.25,0.32,0.43$ are the weight coefficients.

The value of the company's transport activities criterion is calculated according to the formula:

$$
E p=0.25 P l e+0.35 P a+0.40 P s
$$

where $E p$ is the criterion for efficiency of the company's profitability activities;

$P l e$ is the profit per 1 rub of expenses;

$P a$ is the profitability of activity;

$P s$ is the profitability of sales;

$0.25,0.35,0.40$ are the weight coefficients, determined in an expert survey of the AIH «AgroYarsk» workers.

Thus, a comprehensive evaluating the effectiveness of the AIH «AgroYarsk» development by functions (efficiency of supply activities, efficiency of distribution activities, efficiency of warehouse activities, efficiency of transport activities, efficiency of inventory management, efficiency of profitability activities) can have a maximum value of 15 points.

\section{Conclusion}

The study of methods for evaluating the effectiveness of company's development has shown that most of them are limited only to evaluating the overall performance of activities, or to individual elements of activity. In this regard, a new method of evaluating the company's efficiency was developed, which includes evaluating all the main elements of the logistics system using various qualitative and quantitative indicators [21,22]. The proposed method includes evaluating the effectiveness of the company's activities according to its main functions, namely: supply, distribution, warehousing, transportation, inventory management, as well as the overall profitability and profitability of the company's activities.

Also, in order to improve the efficiency of the company's activities, the following measures are proposed:

- sync functions through the development and implementation of the organization's approach of company's functioning;

- $\quad$ implement a stock management system that allows determining the optimal stock size (required for uninterrupted production + insurance stock);

- make decisions based on calculating the optimal size and frequency based on the needs of end-users (for example, production sites) and total operating costs;

- simulate the supply chain using simulation technologies.

- $\quad$ implement a balanced motivation system related to the company's expenditure budget.

The expected performance of the proposed activities is to improve the efficiency of the company, expressed in the growth of profit and profitability, reduced duration of the production and all operational cycle, to reduce operational costs on storage, release from the current economic turnover funds for their reinvestment in other assets, ensuring risk minimization plan to be modified by pre-analysis and modelling of possible development scenarios for events in the supply chain, the growth of labour productivity and economic efficiency of the company, the growth of employee satisfaction, and, consequently, the decrease in staff turnover.

Thus, complex evaluating the effectiveness of company's functioning in the proposed method by functions (supply, distribution, warehousing, transportation, inventory management, as well as the overall profitability and profitability of the company's activities) showed that the efficiency of functioning of the company is estimated at 10.9 points out of 15 (maximum score), that is, the company has some reserves $(27.3 \%)$ to improve efficiency of activities. The company's activity is in the zone of acceptable functioning. The method can be considered universal in the framework of both the processing industry and the agro industrial complex as a whole.

\section{References}

[1] N.V. Alekseenko, Management of sustainable development of industrial enterprises, Economics and management organization, 2, 50-60 (2019).

[2] O.A. Singer, Complex assessment of sustainable development of industrial enterprise, Bulletin of Engecon, 2, 373-378 (2016). 
[3] A.V. Rozhkova, The implementation capabilities of the brand commercial network on the regional market of pasta, IOP Conf. Ser.: Earth Environ. Sci., 315, 022085 (2019).

[4] A.V. Sharopatova, N.I. Pyzhikova, J.A. Olentsova, The current situation of the poultry industry and the formation of a strategy for its sustainable development in the region, IOP Conf. Ser.: Earth Environ. Sci., 421, 022061 (2020).

[5] M G Ozerova, A V Sharopatova and J A Olentsova, The development level and economic efficiency of vegetable production in the Krasnoyarsk region, IOP Conf. Ser.: Earth Environ. Sci., 421, 032049 (2020).

[6] A.V. Rozhkova, M.V. Karaseva, Regional structural export diversification, IOP Conf. Ser.: Earth Environ. Sci., 421, 032015 (2020).

[7] E.V. Stepanova, Export orientation of agribusiness enterprises in the region, IOP Conf. Ser.: Earth Environ. Sci., 421, 032047 (2020).

[8] N. Zhumaniyazov, World practice of creating processing enterprises and the possibility of its application in Central Asia, Information portal of political research, [Electronic resource]. Available at: http:/www.cps.uz/rus/analitics/ publications.

[9] N.A. Dalisova, A.V. Rozhkova, E.V. Stepanova, Russian export of products of maral breeding and velvet antler industry, IOP Conf. Ser.: Earth Environ. Sci., 315, 022078 (2019).

[10] A.V. Rozhkova, J.A. Olentsova, Development of the dairy industry in the region, IOP Conf. Ser.: Earth Environ. Sci., 421, 022035 (2020).

[11] I. Antamoshkina, N.V. Kamenskaya, J.A. Olentsova, The problem of choosing a consumer segment in the agro-industrial complex, IOP Conf. Ser.: Earth Environ. Sci., 421, 022056 (2020).

[12] P. Hazell, C. Poulton, S. Wiggins, A. Dorward, The Future of Small Farms: Trajectories and Policy Priorities, World Development, 38, 10, 1349-1361 (2010). DOI: 10.1016/j.worlddev.2009.06.012.

[13] R.V. Kashbraziev, Model of multi-criteria assessment of regions for rational placement of agricultural enterprises on the territory of the Russian Federation, Actual problems of Economics and law, 7, 25-30 (2017).

[14] T.V. Konovalova, System for evaluating the efficiency of agricultural enterprises, Transport. Science, technology, management, 3, 62-65 (2017).

[15] M.G. Ozerova, A.V. Sharopatova, J.A. Olentsova, Improving the competitiveness of agricultural products as a basis for solving import replacement issues, IOP Conf. Ser.: Earth Environ. Sci., 315, 022026 (2019).

[16] Q.S. Cao, Z.W. Yan, F. Chu, Y.B. Tang, The current situation and countermeasure of development of agricultural clusters in China, Jiangsu Agricultural Sciences, 6, 608-610 (2010).
[17] O.V. Zinina, J.A. Olentsova, The mechanism of increasing the level of sales in credit institutions (banks), Azimuth of Scientific Research: Economics and Administration, 2, 27, 148-152 (2019).

[18] P.A. Benzenko, Formation and development of regional logistics centers of agriculture, Bulletin of the Siberian state automobile and road Academy, 2, 21-28 (2015).

[19] G.L. Brodetsky, P.A. Terentyev, Application of the analytical hierarchy method for optimizing the location of processing enterprises, Logistics and supply chain management, 6, 26-34 (2015).

[20] S. Eliseev, The typology of logistics centers, Logistics, 3, 15-19 (2017).

[21] A.M. Zolotova, Integration trends in the development of regional logistics, Risk: resources, information, supply, competition, 3, 201-211 (2016).

[22] S.V. Kalentiev, Problems of terminology of modern logistics in Russia, Vestnik YUGO. Economics and management, 1, 111-116 (2012). 